\title{
CONTEMPORARY DANMEI FICTION AND ITS SIMILITUDES WITH CLASSICAL AND YANQING LITERATURE
}

Fiksi Danmei Kontemporer dan Persamaannya dengan Sastra Klasik dan Yanqing

\author{
Aiqing Wang \\ Department of Modern Languages and Cultures \\ University of Liverpool \\ aiqing.wang@liverpool.ac.uk
}

\begin{abstract}
Danmei, aka Boys Love, is a salient transgressive genre of Chinese internet literature. Since entering China's niche market in the 1990s, the danmei subculture, predominantly in the form of an original fictional creation, has established an enormous fanbase and demonstrated significance via thought-provoking works and social functions. Nonetheless, the danmei genre is not an innovation in the digital age, in that its bipartite dichotomy between seme 'top' and uke 'bottom' roles bears similarities to the dyad in caizi-jiaren 'scholar-beauty' anecdotes featuring masculine and feminine ideals in literary representations of heterosexual love and courtship, which can be attested in the $17^{\text {th }}$ century and earlier extant accounts. Furthermore, the feminisation of danme $i$ characters is analogous to an androgynous ideal in late-imperial narratives concerning heterosexual relationships during late Ming and early Qing dynasties. Besides, the depiction of semes being masculine while ukes being feminine is consistent with the orthodox, indigenous Chinese masculinity, which is comprised of wen 'cultural attainment' epitomising feminine traits and $w u$ 'martial valour' epitomising masculine traits. In terms of modern literature, danmei is parallel to the (online) genre yanqing 'romance' that is frequently characterised by 'Mary Sue' and cliché-ridden narration.
\end{abstract}

Keywords: danmei genre, 'scholar-beauty' fiction, yanqing romance, feminisation, 'Mary Sue'

\begin{abstract}
Abstrak
Danmei, alias Boys Love, adalah genre transgresif yang menonjol dari sastra internet Tiongkok. Sejak memasuki ceruk pasar China pada 1990-an, subkultur danmei, terutama dalam bentuk kreasi fiksi orisinal, telah membangun basis penggemar yang sangat besar dan menunjukkan signifikansi melalui karya-karya yang menggugah pikiran dan fungsi sosial. Meskipun demikian, genre danmei bukanlah inovasi di era digital, karena dikotomi bipartit antara peran seme 'atas' dan uke 'bawah' memiliki kesamaan dengan angka dua dalam anekdot caizi-jiaren 'cendekiawan-kecantikan' yang menampilkan cita-cita maskulin dan feminin dalam representasi sastra cinta heteroseksual dan pacaran, yang dapat dibuktikan pada abad ke-17 dan catatan yang masih ada sebelumnya. Selanjutnya, feminisasi karakter danmei analog dengan ideal androgini dalam narasi kekaisaran akhir tentang hubungan heteroseksual selama dinasti Ming akhir dan Qing awal. Selain itu, penggambaran para seme menjadi maskulin sementara para uke menjadi feminin konsisten dengan maskulinitas ortodoks Tionghoa asli, yang terdiri dari wen 'pencapaian budaya' yang melambangkan sifat feminin dan wu 'keberanian bela diri' yang melambangkan sifat maskulin. Dalam hal sastra modern, danmei sejajar dengan genre (online) yanqing 'romance' yang sering dicirikan oleh 'Mary Sue' dan narasi yang sarat klise.
\end{abstract}

Kata kunci: genre danmei, fiksi 'scholar-beauty', roman yanqing, feminisasi, 'Mary Sue'

How to Cite: Wang, Aiqing. (2020). Contemporary Danmei Fiction and Its Similitudes with Classical and Yanqing Literature. Jentera: Jurnal Kajian Sastra, 10(1), 127-148. Doi: https://doi.org/10.26499/jentera.v10i1.3397 


\section{INTRODUCTION}

Production and consumption of internet literature in China's cyberspace emerged in the 1990s. They proliferated circa 1995 to 1997, accelerated by the permeation of internet and digital media as well as the marginalisation and retreat of serious literature (Zhang 2003: 230255, Ouyang 2011, Tian and Adorjan 2016), the virtuality of which enables non-professional creation composed by legions of obscure amateur authors with an enormous readership and commercial profits as well as proactive online interaction and participation in a form of commodities (Rifkin 1998: 177, Zhang 2011, Bai 2013). In the digital age, the emergence and popularity of internet literature, along with its commercial success via substantial production and massive consumption, were inspired by an amateur writer pseudonymised Pizizai (1969-), who initially posted his creation on a local Bulletin Board System and received unexpected positive feedback in 1998 (Liu 2004: 154, Chao 2012: 14). Thus, the advent of the $21^{\text {st }}$ century witnessed a prodigious amount of web-based works hosted by pioneering literary websites and virtual communities for commercial and non-commercial purposes (Yin 2005, Chen et al. 2008, Tse and Gong 2012), which has supplanted official cultural offerings as mainstream Chinese popular literature (Li 2007, Ren and Montgomery 2012). According to the latest data released by the China Internet Network Information Centre, by June 2020, there have been approximately 940 million netizens in China, $49.7 \%$ of whom have experience consuming digital literature (China Internet Network Information Centre 2020). The most well-established genres of Chinese internet literature are 玄幺𠃌 xuanhuan 'Eastern fantasy', 都市 $d u s h i$ 'urban', 仙侠 xianxia 'Chinese immortal swordsman' and 网游 wangyou 'online game' (Chao 2012: 114-149), accounting for approximately 50\% of all published fiction on a leading literary website named 起点 Qidian 'Starting Point' (Chao 2012: 34-49).

In the realm of Chinese internet literature, the most salient transgressive genre that has been attaining renown and embracement is dubbed as 耽美 danmei (Zheng 2014, Hockx 2015: 114) that literarily means 'indulgence in beauty; addicted to beauty' and concerns male-male same-sex romance and homoeroticism between attractive pubescent boys and youthful men (Yang and Xu 2016, 2017a, 2017b, Zhang 2016). Chinese danmei literature evolved in the early 1990s from a marginalised niche market (Liu 2009, Yang and Bao 2012, Zhu and Zhang 2015) as a Japanese cultural export of shōnen'ai 'Boys Love', aka BL or yaoi, which draws on the tradition of profoundly romanticised comics featuring 'beautiful young men' for female target viewers since the 1970s (McLelland 2000, Fujimoto 2015, McLelland and Welker 2015, 
Nagaike and Aoyama 2015). Albeit stringent government censorship and surveillance imposed by the party-state (Yi 2013, Ng 2015, Wang 2019) owing to its homosexual essence and interconnection with obscenity (Suzuki 1998, Nagaike 2003, McLelland 2005, 2016, 2017), danmei has managed to accumulate legions of fan producers/consumers (self-)referred to as 腐 女 funü 'rotten girls' (Chao 2016, 2017), following the Japanese terminology fujoshi (Galbraith 2015, Hester 2015, Nagaike 2015). However, owing to its nature as female-oriented, genderinflected fantasies, the vast majority (91-93\%) of danmei fans are surmised to be heterosexual adolescent girls and adult women (Xu and Yang 2014, Zhou and Li 2016, Zeng 2017), prominently those underage fangirls (Zheng 2017, Wang 2018).

Danmei subculture entered a stage of rapid development circa the year 2000 via media such as literary websites and forums, reflected by a salient upsurge in both (young female) producers and consumers (Wei 2014, Xu and Yang 2014, Zhang 2016). Danmei texts are preponderantly accommodated by a leading literary website called 晋江文学城 Jinjiang Wenxue Cheng 'Jinjiang Literature City' (henceforth Jinjiang), which has been hosting a prodigious amount of (non-)fanfiction danmei writing since its launch in 2003 (Yin 2005, Feng 2009, Zheng 2019). The surging popularity and visibility of danmei writing can be justified by the substantial industrial success of Jinjiang. In 2012, numbers of registered users and contracted writers amounted to approximately 5,000,000 and 300,000, respectively (Xu and Yang 2013), yet these figures have impressively surpassed 43,980,000 and 1,650,000 respectively by December 2020 (Jinjiang 2021a).

According to the writer's observation, driven by the ever-growing, gigantic size of fan readership and its corresponding profit and fame, a considerable proportion of producers specialised/interested in other genres and themes have willingly or unwillingly transformed into danmei writers and ingratiated themselves with readers. Early 2013, a celebrated male online writer pseudonymised 南派三叔 Nanpaisanshu (Wang 2020), chef-d'oeuvre of the illustrious, award-winning adventure novel series 盗墓笔记 Daomu Biji 'The Grave Robbers' Chronicles' stated that 一个腐女百万兵, 得腐女者得天下 yige funü baiwan bing, de funü zhe de tianxia 'one funü equals millions of solders; whoever wins the heart of funü conquers the world' ${ }^{1}$ It reveals a direct and bidirectional author-audience interaction and its significant commercial ethos (Feng and Literat 2017).

${ }^{1}$ Unless specified otherwise, all quotations and fiction titles are translated by myself. 
Nonetheless, the leap in danmei's quantity inevitably leads to its deteriorating quality, embodied by the clichéd characterisation, narration, and representation. Although both Japanese BL and Chinese danmei are constituted of textual and visual materials in the form of ACG (Anime, Comic and Games) (Toku 2007, Louie 2012, Aoyama 2015, McLelland 2015), in the Chinese market, fiction is the most-consumed danmei subcategory (Wei 2014), and original fictional creation massively outnumbers its fanfiction counterpart (Xu and Yang 2014). Therefore, in this research, the writer exclusively investigates non-fanfiction contents on Jinjiang, the largest and most successful platform accommodating danmei fiction in China.

\section{RESULT AND DISCUSSION}

\section{Significance of danmei}

There is no denying the fact that the danmei genre assumes a preponderant role in Chinese internet literature and popular subculture, and there is a considerable proportion of danmei fiction that is thought-provoking and invites hermeneutic and interpretive scrutiny.

As mentioned previously, fangirls comprise an overwhelming majority of the Chinese danmei fanbase; parallel to male consumers; male producers are also in a trivial minority compared with their female equivalents (Zhao 2015). An exemplary, prolific male danmei writer publishes under a pseudonym 非天夜翔 Feitianyexiang and arguably a few others such as 顾雪柔 $\mathrm{Gu}$ Xuerou, whose writing is renowned for magnificent standpoints, vivid imaginations as well as a wide range of themes. One of Feitianyexiang's representative works is a realistic-oriented novel 北城天街 Beicheng Tianjie 'Paradise Walk' which is an exception to stereotypical danmei fiction overly fantasising male-male romance, in that it boldly reveals promiscuity, one-night stands, AIDS, and decease (Zhao 2015). Another best-selling book 二 零一三 Erlingyisan '2013' is an apocalyptic novel enriched by complex, multi-faceted characters, which outperforms mediocre web-based pulp fiction through evoking film-like imagery of landscapes and figures as well as conveying values such as heroism, patriotism, and humanism (Xiao 2019). The artistic value of Feitianyexiang's writing is also demonstrated by profound historical and literary allusions as well as an integration of the traditional 演义 yanyi 'popular explication; the exposition of the meaning of events in history' (McLaren 2006, Ge 2007) and 武侠 wuxia 'Chinese knighthood; martial chivalry' (Liu 1967: 2, Teo 2009: 2, To 2019), as in 天宝伏妖录 Tianbao Fuyao Lu 'A Chronicle of Subduing Demons in the Tianbao Period' (Xiao 2018). What is noteworthy is that in Feitianyexiang's historical stories 
exemplified by 破罐子破摔 Poguanzi Poshuai 'To Smash a Cracked Jar', female characters are not depicted as men's possessions, but intelligent and independent participants and creators of history (Xu and Yang 2014).There are, of course, myriads of outstanding danmei narratives composed by female authors. For instance, 天官赐福 Tianguan Cifu 'Blessing from Heavenly Officials', the chef-d'oeuvre of a contentious Jinjiang writer pseudonymed 墨香铜臭 Moxiangtongxiu, has been ranking the highest on readers' voting list on Jinjiang since its release in 2017 and has received an average of 2,396,071 views per chapter and 1,955,548 comments by January 2021 (Jinjiang 2021b). Notwithstanding controversies and fan quarrels, and conflicts, the writer has argued that this work exhibits ethic-religious ideologies, feminist thinking, and the complexity of human nature (Author 2020).

In terms of danmei media representation, apart from commercially-targeted and officiallyexpurgated online dramas such as 陈情令 Chenqingling 'The Untamed' and 镇魂 Zhenhun 'Guardian' (Wang 2019), there are reality-oriented and materially-grounded visual contents. That the exploration of neoliberalism, queer sexuality, and social disparity are exemplified by films 双程 Shuangcheng 'A Round Trip to Love' and 不可抗力之男仆的秘密 Bukekangli Zhi Nanpude Mimi 'Uncontrolled Love' (Wong 2020), and an online serial 上瘾 Shangyin 'Addicted' that has been banned for 'exaggerat[ing] the dark side of society' and '[show]ing abnormal sexual relationships and behaviours' (Campbell 2016, Ellis-Petersen 2016).

The significance of danmei fiction lies in a variety of aspects. Female 'rotten' readers are impinged upon by negative self-image induced by gender-related anxiety, which can be mitigated by danmei writing through fictionally constructed masculinity and expression of repressed sexual carnality (McLelland 1999, Wood 2006, Kamm 2013, Zsila and Demetrovics 2017). That is to say; female danmei consumers are permitted to exhibit and share their fascination for youthful male bodies in an uninhibited fashion (Greer 2003: 10, McLelland 2005, 2017, Zsila et al. 2018) and delight in aberrant and transgressive acts and sexual ecstasy by means of identifying with male characters (Nagaike 2003, 2015, Nagaike and Aoyama 2015), with reduced apprehension while consuming scenes of sexual violence (Fujimoto 2004, 2015). In a word, danmei fiction enables readers to attain aesthetics, escapism, voyeurism, gender equality, as well as the release of normative gender prescriptions and norms (Chou 2010, Zhang 2016, Lilja and Wasshede 2017). Therefore, danmei literature is construed quintessential as an 'oppositional discourse' that is deviant from orthodox genres and conventional cultural institutions (Martin 1986: 44-45, Wei 2008, Xu and Yang 2013). 


\section{Caizi-jiaren vs seme-uke}

In an iconic masterpiece 红楼梦 Hong Lou Meng 'The Story of the Stone; Dream of the Red Chamber/Mansion' that chronicles prosperity, travails, and catastrophic perishment of a populous aristocratic clan, the author Cao Xueqin (1724-1764) expresses incisive animadversions regarding clichéd 才子佳人 caizi-jiaren 'scholar-beauty' anecdotes surrealistically overemphasising non-arranged romantic and matrimonial relationships, via a sagacious character Grandmother Jia (Zhang 2012) (Example (1)).

(1) 开口都是乡绅门第, 父亲不是尚书, 就是宰相。一个小姐, 必是爱如珍宝。这小姐必是通文知 礼, 无所不晓,

竟是 “绝代佳人”, 只见了一个清俊男人, 不管是亲是友, 想起他的终身大事来, 父母也忘了, 书也 忘了, 鬼不

成鬼, 贼不成戌, 那一点儿像个佳人? 就是满腹文章, 做出这样事来, 也算不得是佳人了。比如一 个男人家,

满腹的文章, 去做贼, 难道那王法看他是个才子就不入贼情一案了不成?

Kai kou dou shi xiang shen men di, fu qin bu shi shang shu, jiu shi zai xiang. Yi ge xiao jie, bi shi ai ru zhen bao.

Zhe xiao jie bi shi tong wen zhi li, wu suo bu xiao, jing shi 'jue dai jia ren', zhi jian le yi ge qing jun nan ren, bu guan shi qin shi you, xiang qi ta de zhong shen da shi lai, fu mu ye wang le, shu ye wang le, gui bu cheng gui, zei bu cheng zei, na yi dian er xiang ge jia ren? Jiu shi man fu wen zhang, zuo chu zhe yang shi lai, ye suan bu de shi jia ren le. Bi ru yi ge nan ren jia, man fu de wen zhang, qu zuo zei, nan dao na wang fa kan ta shi ge cai zi jiu bu ru zei qing yi an le bu cheng?

'Invariably, we are told how well-born they are. Their father has been a Prime Minister or a First Secretary at the very least. They are always their father's only child and the apple of his eye. They are always amazingly well-educated, a model of decorum, a regular paragon of all the virtues-that is, until the first presentable young man comes along. As soon as he appears on the scene-it doesn't matter who or what he is-all their book-learning and the duty they owe their parents fly out of the window and the next moment they are "making their plans for the future" and generally carrying on in a way that would bring blushes to the cheek of a cat-burglar-certainly not in the least like respectable, educated young ladies. You would hardly call a young woman who conducted herself like that a "paragon", however many books she might have read-any more than you would acquit a young fellow charged with highway robbery on the grounds that he was a good scholar.'

(Hong Lou Meng. Chapter 54. Trans. Hawkes 1973)

Caizi-jiaren 'scholar-beauty' fiction serves as a terminology of multiple connotations, epitomising masculine, and feminine ideals in literary representations of heterosexual love, courtship, and sexuality in pre-modern China, in which the heroes are portrayed as fragile scholars indicating a cultural discourse and self-representation of Confucian literati based on their social and political anxiety and narcissism (Song 2004: 19, 41). Caizi-jiaren fiction prominently appeared in the $17^{\text {th }}$ century. However, extant records can be attested in anecdotes regarding the love affair between Sima Xiangru (179-117BC) and Zhuo Wenjun (150-115BC) of the Han (202BC-220AD) dynasty and 莺芶传 Yingying Zhuan 'The Biography of Yingying' 
in the Tang (618-907) dynasty (Huang 2001: 206). As illuminated by the name, cai 'literary talent' is the defining property of caizi; the other indispensable component of caizi is qing which entails sensibility and subversiveness (Song 2004: 3, 104), so caizi-jiaren fiction highlights romantic elements, e.g. celebration of poetic talent, secret rendezvous between lovers in rear gardens, the adamant pursuit of happiness albeit hindrances, etc. (Huang 2003).

Contemporary danmei literature, in stark contrast to the Western slash marked by versatility (Xiao 2018), tends to demonstrate a patent, non-reversible bipartite dichotomy between 攻 gong 'seme' (top; insertive) and 受 shou 'uke' (bottom; receptive) roles, rather than the so-called 互攻 hugong 'versatile' mode, partially owing to the aesthetics and conventions of Japanese BL products (Yang and Xu 2017b). Such a conspicuous seme-uke dyad defines the seme as the dominant penetrator. However, as the passive receiver, the uke is prone to display physically and emotionally feminine stereotypes, so it is anathematised to reproduce the patriarchal gender hierarchy (Pagliassotti 2010, Zhang 2016) and comply with a heteronormative frame (Zhao and Madill 2018).

Danmei narratives featured by a well-defined top-bottom discrepancy frequently adopt a strong seme $\times$ weak uke bipartite dichotomy, in which the uke characters are fundamentally jiaren-like, comprising a heterosexual cai-jiaren pattern with the semes. In danmei fandom, enfeebled and feminised ukes are affectionately referred to as 娘(炮)受 niang(pao) shou 'sissy ukes', who are stereotypically paired with virile semes labelled as 强攻 qiang gong 'strong seme’ or 流讯攻 liumang gong ‘hooligan seme', as in novels 樱桃树下 Yingtao Shu Xia 'Under the Cherry Tree' and 精英攻和伪娘受的故事 Jingyinggong He Weiniangshoude Gushi ‘Story between an Elite Seme and a Fake-Girl Uke'. For instance, in 娘娘腔 Niangniangqiang 'Nancy', the characterisation of the seme and that of the uke are discrepant, as in Example (2) and (3) respectively.

(2) 他想起了第一次见到邵群时的场景, 那时候邵群看上去就是一个高贵优雅的小王子。后来才 知道邵群除

了那层骗人的皮囊外, 实际上根本是个不折不扣的小流讯, 什么打架斗殴聚众闹事欺负老师同学 的事他都

掺和。

Ta xiang qi le di yi ci jian dao shao qun shi de chang jing, na shi hou shao qun kan shang qu jiu shi yi ge gao gui

you ya de xiao wang zi. Hou lai cai zhi dao shao qun chu le na ceng pian ren de pi nang wai, shiji shang gen

ben shi ge bu zhe bu kou de xiao liu mang, shen me da jia dou ou ju zhong nao shi qi fu lao shi tong xue de shi ta dou chan huo. 
'He recalled his first impression of Shao Qun, who looked like a noble, elegant little prince. Then he found himself

deceived by Shao Qun's looks: he was an absolute hooligan initiating all sorts of troubles like fighting, bullying fellow students and hectoring teachers.'

(Niangniangqiang. Chapter 2. Trans. Mine)

(3) 一个年近三十的男人, 瘦弱得跟高中生似的, 怎么形容呢, 就是弱不禁风。一个男人啊, 让人 觉得弱不禁风,

还有救吗。这也就算了, 讲话声儿小得让人恨不得给他嘴上安个喇叭, 一副低眉顺眼的娘们儿样, 就这样

的, 穿个裙子走出八里地, 都不带有人看出不对劲儿的。他知道他们酒店有些年轻的小工, 爱背 地里学他

说话和走路姿势, 还要额外配个兰花指吊吊眉角什么的。

Yi ge nian jin san shi de nan ren, shou ruo de gen gao zhong sheng shi de, zen me xing rong ne, jiu shi ruo bu jin

feng. Yi ge nan ren a, rang ren jue de ruo bu jin feng, hai you jiu ma. Zhe ye jiu suan le, jiang hua sheng er xiao

de rang ren hen bu de gei ta zui shang an ge la ba, yi fu di mei shun yan de niang men er yang, jiu zhe yang de,

chuan ge qun zi zou chu ba li di, dou bu dai you ren kan chu bu dui jin er de. Ta zhi dao ta men jiu dian you xie

nian qing de xiao gong, ai bei di li xue ta shuo hua he zou lu zi shi, hai yao e wai pei ge lan hua zhi diao diao mei

jiao shen me de.

'He was in his late twenties yet still as scrawny as a teenager. The word "emaciated" could best describe him-he

was so frail that he could be knocked down by a puff of breath. Wasn't this "man" hopeless! Worse still, others

wished to install an amplifier on him in order to hear his murmur. He was such a meek sissy that even if he walked

in a skirt for miles, nobody would notice anything wrong. Some young kitchen staff enjoyed mimicking the way

he spoke and walked behind his back, and they always exaggerated by crooking little fingers and making eyes.'

(Niangniangqiang. Chapter 1. Trans. Mine)

Apart from the heterosexual essence, the similitude between caizi-jiaren and danmei also lies in their analogous theme and plots. Although early in the $18^{\text {th }}$ century, Cao Xueqin disdained the overemphasis on love in caizi-jiaren romances, some modern danmei novels may still treat romance as the sole theme. Given the fact that danmei fiction enables readers to identify with the uke role, in this sense, danmei tales bear resemblance to 爽文 shuangwen 'feel-good writing' that enhances reading enjoyment by means of unrealistic storylines and depictions. To be more specific, although being female-oriented, some danmei products are parallel to male-authored, blatantly-presented and Web-based fantasies that are unflatteringly coined as 种马文 zhongma 'stud fiction' (Feng 2013: 10). Male protagonists in time-travel 'stud fiction' are always blessed by an authorial 金手指 jin shouzhi 'golden finger' to conquer 
the past with modern technologies and reverse history completely; more importantly, these heroes possess stud-like virile prowess to obtain numerous beautiful women simultaneously, and hence the name of this subcategory of writing (Feng 2013: 38, 93). As a consequence of this common attribute, some Chinese Internet novels are nicknamed YY 小说 YY xiaoshuo ' $\mathrm{YY}$ fiction', in which YY denotes 意淫 yiyin 'lust of the mind', viz. explicit exploration of mental lascivious fulfilment (Chao 2012: 225, Hockx 2015: 112).

\section{Feminisation in Classical literature and danmei}

In late-imperial Chinese literature during late Ming (1368-1644) and early Qing (1644-1912) dynasties, works depicting heterosexual relationships, including both romantic and historical novels (Wu 2003), are replete with an androgynous ideal concerning heroes with a feminised appearance (Louie 1999, Louie and Edwards 1994, Hodge and Louie 1998:129130). For instance, the typical feminised image of caizi in Ming-Qing fiction is marked by 'rosy lips, sparkling white teeth, jasper-like face', embodying conventional aesthetics of males; although the effeminacy of caizi is not attributed to homosexuality, it indeed encapsulates social tolerance towards homosexuality and the lack of homophobic discourse in traditional China, so the fragility of scholars does not undermine the gender order (Song 2004: 125-126). Similarly, in a late Ming erotic tale highlighting graphic sexual depictions and valorisation of feminised males, 浪史 Langshi 'Tales from a Life of Indulgence', the lascivious seducer's feminised demeanour acts as irresistible attractiveness to both experienced women and innocent maidens: '[a]s her ladyship gazed upon Langzi she found him to be just like a beautiful woman, sporting an ivory complexion and fine features, returning her look with a dreamy smile. Uncontrollable passions flooded over her' (Wu 2003: 22).

The orthodox, indigenous Chinese masculine ideal is constituted of two facets, viz. 文 wen 'cultural attainment' signifying feminine traits, and 武 $w u$ 'martial valour' signifying masculine traits (Louie 2002), with the former deemed as the embodiment of power and privilege, and hence superior to the latter (Louie 2000, 2014). The civil wen is inextricably intertwined with Confucian masculinity and its creed of 君子 junzi 'gentleman' (Louie 1991, 2003), and the preponderance of wen can be reflected by epicene, fragile 才子 caizi 'scholars' and 文人 wenren 'literati' epitomising exemplary masculinity in premodern China (Song 2004: 157-158, Louie 2013, 2014). 
In contemporary China, the restructured masculine ideal subtly yet preponderantly departs from the orthodox zeitgeist, thereby becoming more 'softened' and feminised (Louie 2000, 2012). The 'soft' masculinity functions as a novel form of male aesthetics and trend of 'consumption of sexualised men' under the female gaze (Hu 2017, Zhou 2017, Li 2020). Impinged upon by media and industry promulgating a gender ambiguous popular culture, Chinese adolescents adore 小鲜肉 xiao xian rou 'little fresh meat', viz. effeminate-looking, delicate-featured and makeup-clad youthful male idols (Buchenbacher 2018, Keegan 2018, Gao 2019), whose emergence and popularity indicate the increasing (purchase) power of women and consumerism (Jung 2009, 2011: 39, Zhang and Negus 2020). In danmei fiction, both seme and uke characters are conventionally featured by androgyny and effeminacy. For instance, in 髸边不是海棠红 Binbian Bushi Haitanghong 'Begonias on Sideburns' themed on Peking Opera, the feminised seme and uke are depicted in Example (4) and (5) respectively.

\footnotetext{
(4) 秀眉俊目的一张瘦长脸儿, 奶白的肤色, 睫毛太长太浓, 显得有些脂粉气。

Xiu mei jun mu di yi zhang shou chang lian er, nai bai de fu se, jie mao tai chang tai nong, xian de you xie zhi

fen qi.

'He had a diamond-shaped, delicate-featured face with stunning eyes and eyebrows. The eyelashes were too long and too thick, rendering this fair-skinned young man somehow feminine.'

(Binbian Bushi Haitanghong. Chapter 2. Trans. Mine)

(5) 商细芯跟个姑娘似的娇娇柔柔弱不禁风。

Shang xi rui gen ge gu niang shi de jiao jiao rou rou ruo bu jin feng.

'Shang Xirui was as feeble as a delicate girl who could not even stand a gentle breeze.' (Binbian Bushi Haitanghong. Chapter 5. Trans. Mine)
}

There is no denying the fact that in vernacular fiction of the late $18^{\text {th }}$ and early $19^{\text {th }}$ centuries, there are male protagonists who are 文武双全 wenwu shuangquan 'distinguished in both literary and military arts' (Huang 2003). In danmei literature, since the tale naturally contains two male protagonists, it is also common to divide the wen-wu dyad by depicting a masculine seme encapsulating $w u$ and a feminine uke encapsulating wen. For instance, in detective novels SCI 谜案集 SCI Mianji 'Collection of Cases from Special Criminal Investigation' and 犯罪心理 Fanzui Xinli 'Criminal Psychology', both authors make the wu semes policemen while the wen ukes psychologists; in Feitianyexiang's historical stories such as 鹰奴 Yingnu ‘Eagle Slave’ and 相见欢 Xiangjianhuan 'Ecstasy of Encounters', the semes are routinely equipped with martial arts, while the ukes are analogous to fragile caizi with intellectual aptitude. Nonetheless, according to Li (2017), the masculinity of heroes in 
Classical and modern literature lies in their spirit, yet danmei literature places an emphasis on visual aesthetics.

\section{Yanqing vs danmei}

In late Qing, the traditional caizi-jiaren genre evolved into 助莺蝴蝶派 yuanyang hudie pai 'Mandarin Duck and Butterfly School' that narrates sentimental stories pertaining to unfulfilled romantic encounters with bad endings and sorrowful, bitter, miserable, wronged or chaste love (Link 1977: 22, 332-333, Chow 1991: 51, Tan 2016). Despite the censure accompanied by the May Fourth Movement, 'Mandarin Duck and Butterfly' had sustained popularity for decades in multimedia forms (Hsia 1982, Chow 1986, 1991: 36-38) and contributed to Chinese popular literature ( $\mathrm{Li} 2012)$.

In the modern age, caizi-jiaren romance has been rejuvenated into 言情 yanqing 'romance' since China's economic reforms in the 1980s, represented by works of a phenomenal writer 琼瑶 Qiongyao (Chao 2012: 159, Hockx 2015: 112). Qiongyao (1938-) is an illustrious mainland-born Taiwan romance writer who is acclaimed as the 'Queen of Romance' and reigned the Chinese popular romance field for over three decades. Although her writing attracted legions of fans in the 1980s and 1990s and her works are still adapted for television serials and films, Qiongyao has been consistently ridiculed and disdained by critics, peer writers, outspoken readers and scholars of modern literature (Lee 1980: 25, Nielsen 2000, Lang 2003). Moreover, in the current cyberspace, Qiongyao is overwhelmingly castigated in moralistic discourses by Chinese women for her melodramatic narrative style, glorification of extramarital affairs and authorial misguidance deviant from traditional Chinese values; her heroines are also anathematised for feigning vulnerability and naivety and ingratiating themselves with patriarchal power in order to monopolise resources (Feng 2013: 7-10). In online fandom, the terminology yanqing can be substituted by a neologism BG (boy-girl) to denote heterosexualoriented literature within a heteronormative and patriarchal frame.

The terminology 'Mary Sue' is deployed by producers and consumers of fanfiction to pejoratively denote idealised and flawless female fictional characters of beauty, power and courage (Pflieger 1999, Chander and Sunder 2007), which is perceived to be thinly disguised versions of authors' idealised self and narcissism (Smith 1973, Collins 2018: 19). Although 'Mary Sue' has been adopted and transliterated into 玛丽苏 malisu since the advent of the $21^{\text {st }}$ century, this terminology has been Sinicised in China's Internet literature market, in that it more 
pertains to yanqing, rather than fanfiction; more importantly, 'Mary Sue' elements are not imported, as they can be attested in indigenous works such as those composed by Qiongyao (Sun and Shi 2016, Zheng 2017). Chinese 'Mary Sue' textual and audio-visual works are characterised by claimed feminist thinking (Liu 2018), in that heroines' attainment of success, fortune and status is fundamentally bestowed by heroes and supporting roles, all of whom adore heroines (Zheng 2017) and are disposed to sacrifice themselves so as to protect or facilitate the heroines (Zhang 2015, Liu 2017). Moreover, Chinese 'Mary Sue' intensifies the stigma and repression imposed on women by the patriarchal system through promulgating idealised femininity or an enriched image of 'Cinderella' (Wang 2017), and it links women's independence with their obligation to attract men and obtain love (Sun and Shi 2016).

The phenomenal 2015 TV serial 琅躯榜 Langyabang 'Nirvana in Fire' was initially published as a danmei narrative and later converted into a historical one with heterosexual romance; since the protagonist was initially designed as a uke, the novel has been treated as a male version of a 'Mary Sue' story, viz. 杰克苏 jiekesu 'Gary Stu' (Guan 2016, Wang 2017). In danmei fiction with a 'Gary Stu' pattern, in order for protagonists and deuteragonists to fall in love with each other at first sight or to charm other characters, they are equipped with stunning appearance, as in 势不可挡 Shibukedang 'Invincible' and 睡我上铺的男神 Shui Woshangpude Nansheng 'The Prince Charming Sleeping on the Top Bunk of My Bed'; the attractiveness of heroes is also embodied by their multiple suitors, as in 不死者 Busizhe 'The Immortal' and 乱世为王 Luanshi Weiwang 'The King of Turbulent Times'. Furthermore, an updated characterisation can be summarised by a neologism 高富帅 gao fu shuai 'tall, rich, handsome', as in 图灵密码 Tuling Mima 'Turing's Code', 默读 Modu 'Subvocalisation' and 残次品 Cancipin 'Defective Products'. Furthermore, to stress the profoundness of love, danmei characters may unwaveringly wait for decades in an immorality cultivation setting, as in 魔道 祖师 Modao Zushi ‘Grandmaster of the Fiend Dao' and 阴客 Yinke 'The Underworld'.

Furthermore, online yanqing tales marked by 'Mary Sue' attributes are chastised by the mainstream literature for being 'vulgar' by virtue of the clichéd storyline of 霸道总裁爱上我 badao zongcai aishang wo 'a domineering boss falls in love with me', which may deploy other occupations such as doctors, professors and army officers yet still adopt the same nature as feelgood writing (Wu and Zhang 2018). Similarly, danmei fiction is replete with such a ‘domineering boss’ pattern, as in 总裁酷帅狂霸拽 Zongcai Ku Shuai Kuang Ba Zhuai 'The 
Cool, Handsome, Arrogant and Domineering Boss', 总裁和他的秘书 Zongcai He Tade Mishu ‘The Boss and His Secretory', 写实派玛丽苏 Xieshipai Malisu 'Realistic Mary Sue', etc. Additionally, 'Mary Sue' yangqing and 'Gary Stu' danmei share other similitudes.

(1) In both types of Internet literature, characters featured by 美强惨 mei qiang can 'beautiful, powerful, pitiful' are comprehensively embraced by readers. In Chinese fandom, devotees' overwhelming passion for celebrities is attributed to a construal of their idols being mei qiang can: fans believe that idols are blessed with outstanding appearance and talent, i.e. 'beautiful' and 'powerful', whereas they are exploited by the avaricious show business and besmirched by abhorrent competitors and their fanbases, thus being 'pitiful'. As a consequence, fans have established a quasi-sufferer-martyr relation with stars in a religious mode (Xie and Zhang 2020). Similarly, in yanqing and danmei fiction, protagonists are frequently portrayed as being mei qiang can, thereby attracting fan readership, as in a danmei novel 反派他 过分美丽 Fanpai Ta Guofen Meili 'The Antagonist is Excessively Beautiful' and its sequel 全道门都欠我一个人情 Quandaomen Dou Qianwo Yige Renqing 'The Entire Taoist Cultivation World Owes Me'.

(2) Parallel to yanqing, danmei fiction tends to emphasise 双洁 shuangjie 'both purity', an Internet neologism coined to refer to the chasteness of both partners in hetero- or homosexual relationships. On Jinjiang, if seme and/or uke protagonists have sexual encounters with other people, in the 文案 wenan 'introductory/summary page' authors may choose to post warnings, and such an act is metaphorically referred to as 排雷 pailei 'to clear mines'. For instance, in 一生锦衣 Yisheng Jinyi 'Lifelong Sumptuous Clothing', the author warns readers that 双不洁, 慎点 shuangbujie, shendian 'neither protagonist is chaste; think twice before reading'; in 无路可退 Wulu Ketui 'No Way Back', the warning is as explicit as 小受菊不洁 xiaoshou ju bujie 'uke's anus is unchaste'. I postulate that one of the reasons accounting for fan readers' preference for shuangjie characterisation lies in their age. In China's cyberspace, $38.2 \%$ of netizens are under the age of 30 , and $18.3 \%$ of them are under 20 (China Internet Network Information Centre 2020); in the online danmei community, fans below the age of 22 amounted to $78.43 \%$ of the entire readership in 2016 , and $82.35 \%$ of fans started consuming danmei fiction before 18 years old (Zheng 2017). To accommodate young readers with relatively less sexual/life experience, danmei narratives with modern settings need to justify the fact that those attractive protagonists in their twenties or even thirties are still void of sexual and/or love experience: in a detective novel 破云 Po Yun 'Breaking Clouds' and its sequel 吞海 Tun Hai ‘Swallowing Oceans', the explanations are designed to be busy work, undercover duties and determined revenge. In campus narratives, since protagonists are younger, readers' shuangjie preference is easier to be satisfied, as in 过门 
Guomen 'Passing the Gate' and 狼行成双 Langxing Chengshuang 'A Pair of Wolves'.

(3) Analogous to yanqing, danmei writing abounds in the so-called storyline of 追妻火 葬场 zhuiqi huozangchang 'chasing the wife to the crematorium', which is an Internet neologism indicating the clichéd plot that the hero/seme initially ignores or hurts the feelings of the heroine/uke and later strives to win the latter's heart back. In these danmei works, callous semes are labelled as 渣攻 zhagong 'bastard seme', represented by the contentious series novels nicknamed ' $188 \mathrm{~cm}$ band' by 水千丞 Shuiqiancheng, in which most semes emotionally and physically abuse the ukes yet eventually realise their love and have happy endings.

Owing to the homosexual nature, plots appearing in yanqing stories such as social acceptance, marriage and childbearing might not always be applicable in danmei narratives. Danmei writers, however, still manage to create plots that accord with the heterosexual framework. In contemporary China, most people hold conservative attitudes towards homosexuality: according to data from the Chinese General Social Surveys 2013, approximately $78.53 \%$ of the respondents deemed seme-sex sexual intercourse wrong (Xie and Peng 2018). Therefore, in danmei writings with a modern setting, writers tend to create orphan protagonists, thereby circumnavigating the hindrance from parents, as in 大哥 Dage 'Elder Brother' and 山河表里 Shanhe Biaoli 'Mountains and Rivers'. Additionally, pregnancy or childbearing is portrayed in period and modern yanqing fiction to manifest the completeness of a patriarchal family with male heirs, and such depiction also occurs in a danmei subgenre dubbed as 生子文 shengzi wen 'childbirth writing' that features male pregnancy and childbearing and is increasingly visible on Jinjiang and online discussion forums (Tian 2015). Uke's pregnancy and childbirth appear not only in stories with an omegaverse (aka ABO) setting that surrealistically concerns blurred biological roles, but also in fantasy, time travel and 'realistic' contexts, exemplified by 穿成 Omega 后发现自己怀孕了 Chuancheng Omega Hou Faxian Ziji Huaiyunle 'Becoming a Pregnant Omega After Time Travel', 提灯映桃花 Tideng Ying Taohua 'Peach Blooms Illuminated by a Lamp', 怀了豪门老男人的崽 Huaile Haomen Laonanrende Zai 'Pregnant with a Rich Old Man's Baby', etc. Alternatively, danmei partners are depicted to comply with the heteronormative norms and patriarchal structure via surrogacy (as in 离婚 Lihun 'Divorce') or adoption (as in 乱世为王 Luanshi Weiwang 'King of Turbulent Times'), and there may be substitutes for offspring, such as pets (as in 死亡万花筒 Siwang Wanhuatong 'Kaleidoscope of Death'), cultivation apprentices (as in 六爻 Liuyao 'Hexagram'), 
supernatural beings (as in 我五行缺你 Wo Wuxing Que Ni'You Are Missing From My Five Elements'), etc.

\section{CONCLUSION}

Danmei genre falls under the category of internet literature, yet it bears a resemblance to classical literature. The patent, non-reversible bipartite seme-uke dichotomy in danmei narratives coincides with the masculinity-femininity dyad and heteronormative norms indicated in caizi-jiaren anecdotes. Moreover, the fragile scholars in caizi-jiaren romances demonstrate androgynous demeanour, parallel to feminised danmei characters and the 'soft' masculinity prevailing in contemporary China. In terms of fiction of the late $18^{\text {th }}$ and early $19^{\text {th }}$ centuries, in which male protagonists are equipped with both wen and $w u$ attributes, it is analogous to danmei, in that the wen-wu dyad is divided into a masculine seme embodying $w u$ and a feminine uke embodying wen.

In the field of popular romance, danmei bears similitude with yanqing, though the latter pertains to heterosexuality and complies with a heteronormative and patriarchal frame. In particular, danmei fiction, similar to its yanqing counterpart, abounds in cliché-ridden storylines and depictions as well as 'Mary Sue' and 'Gary Stu'. Apart from idealised masculinity and homoerotic intimacy, danmei narratives frequently enable protagonists to possess chasteness and 'beautiful, powerful, and pitiful' properties and deploy clichéd plots of 'chasing the wife (uke) to the crematorium'. Additionally, danmei is on a par with yanqing in terms of depictions manifesting the completeness of a patriarchal family with male heirs through substitutes for offspring or the 'childbirth writing' subgenre entailing male pregnancy.

\section{REFERENCES}

Aoyama, Tomoko. (2015). Queering the cooking man: food and gender in Yoshinaga Fumi's (BL) manga. In Boys Love Manga and Beyond: History, Culture, and Community in Japan, Eds. Mark McLelland, Kazumi Nagaike, Katsuhiko Suganuma and James Welker, 233-252. Jackson: University Press of Mississippi.

Bai, Shi. (2013). The Rise of Internet Literature: An income list reveals the growth of cyber novels and novelists. Beijing Review. 03 January 2013. http://www.bjreview.com.cn/print/txt/2012-12/29/content_509734.htm.

Büchenbacher, Katrin. (2018). China's meat divide. Global Times. 19 July 2018. https://www.globaltimes.cn/content/1111499.shtml.

Chao, Shih-chen. (2012). Desire and Fantasy On-Line: A Sociological and Psychoanalytical Approach to the Prosumption of Chinese Internet Fiction. PhD thesis. University of Manchester.

Chao, Shih-chen. (2016). Grotesque Eroticism in the Danmei Genre: The Case of Lucifer's 
Club in Chinese Cyberspace. Porn Studies 3.1: 65-76.

Campbell, Charlie. (2016). Chinese Censors Have Taken a Popular Gay Drama Offline and Viewers Aren't Happy. Time. 25 February 2016. https://time.com/4236864/china-gaydrama-homosexuality/.

Chander, Anupam and Madhavi Sunder. (2007). Everyone's a Superhero: A Cultural Theory of 'Mary Sue' Fan Fiction as Fair Use. California Law Review 95.2: 597-626.

Chen, Ying-Hueih, Jyh-Jeng Wu and Yu-Shuo Chung. (2008). Cultural Impact on Trust: A Comparison of Virtual Communities in China, Hong Kong, and Taiwan. Journal of global information technology management 11(1): 28-48.

China Internet Network Information Centre. (2020). The $46^{\text {th }}$ China Statistical Report on Internet Development. Cyber Administration of China. September 2020.

Chou, Dienfang. (2010). Exploring the meaning of Yaoi in Taiwan for female readers: From the perspective of gender. Intercultural Communication Studies 19: 78-90.

Chow, Rey. (1986). Rereading Mandarin Ducks and Butterflies: A Response to the 'Postmodern' Condition. Cultural Critique 05: 69-93.

Chow, Rey. (1991). Woman and Chinese Modernity: The Politics of Reading Between West and East. Minneapolis, MN: University of Minnesota Press.

Ellis-Petersen, Hannah. (2016). China bans depictions of gay people on television. The Guardian. 04 March 2016. https://www.theguardian.com/tv-andradio/2016/mar/04/china-bans-gay-people-television-clampdown-xi-jinping-censorship.

Feng, Jin. (2009). 'Addicted to Beauty': Consuming and Producing Web-Based Chinese Danmei Fiction at Jinjiang. Modern Chinese Literature and Culture 21.2: 1-41.

Feng, Jin. (2013). Romancing the internet: Producing and consuming Chinese web romance. Danvers, MA: Brill.

Feng, Yuyan and Ioana Literat. (2017). Redefining Relations Between Creators and Audiences in the Digital Age: The Social Production and Consumption of Chinese Internet Literature. International Journal of Communication 11: 2584-2604.

Fujimoto, Yukari. (2015). The evolution of bl as 'playing with gender': Viewing the genesis and development of BL from a contemporary perspective. In Boys Love Manga and Beyond: History, Culture, and Community in Japan, Eds. Mark McLelland, Kazumi Nagaike, Katsuhiko Suganuma and James Welker, 76-92. Jackson: University Press of Mississippi.

Galbraith, Patrick W. (2015). Moe talk: Affective communication among female fans of yaoi in Japan. In Boys Love Manga and Beyond: History, Culture, and Community in Japan, Eds. Mark McLelland, Kazumi Nagaike, Katsuhiko Suganuma and James Welker, 153168. Jackson: University Press of Mississippi.

Gao, Helen. (2019). 'Little Fresh Meat' and the Changing Face of Masculinity in China. The New York Times. 12 June 2019. https:/www.nytimes.com/2019/06/12/opinion/littlefresh-meat-china.html.

Ge, Liangyan. (2007). Sanguo yanyi and the Mencian View of Political Sovereignty. Monumenta serica 55(1): 157-193.

Greer, Germaine. (2003). The Beautiful Boy. New York: Rizzoli International Publications. Hawkes, David. 1973. Trans. The story of the stone. Vol I-V. Middlesex: Penguin Books.

Guan, Xuelian. (2016). Malisu shenhuade lishi liju, xushi fanwei he shenmei quwei [History, narrative scopes and aesthetic preference of Mary Sue stories]. Literary Review 04: 165170.

Hester, Jeffry T. (2015). Fujoshi emergent: Shifting popular representations of yaoi/BL fandom in Japan. In Boys Love Manga and Beyond: History, Culture, and Community in Japan, eds. Mark McLelland, Kazumi Nagaike, Katsuhiko Suganuma and James Welker, 169- 
189. Jackson: University Press of Mississippi.

Hockx, Michel. (2015). Internet Literature in China. New York: Columbia University Press.

Hodge, Bob and Kam Louie. (1998). The politics of Chinese language and culture: The art of reading dragons. London: Routledge.

Hsia, Chih-tsing. (1982). Hsu Chen-ya's Yu-li hun: An Essay in Literary History and Criticism. Renditions 199-240.

Hu, Chaokai. (2017). Deciphering 'Nan Se consumption' under consumerist culture. Journal of News Research 8.22: 83-86.

Huang, Martin W. (2001). Desire and Fictional Narrative in Late Imperial China. Cambridge: Harvard University Press.

Huang, Martin W. (2003). From Caizi to Yingxiong: Imagining Masculinities in Two Qing Novels, 'Yesou puyan' and 'Sanfen meng quan zhuan'. Chinese Literature: Essays, Articles, Reviews 25: 59-98.

Jinjiang Literature City. (2021). Guanyu Jinjiang [About Jinjiang]. http://www.jjwxc.net/aboutus/.

Jinjiang Literature City. (2021). Tianguan Cifu [Blessing from Heavenly Officials]. http://www.jjwxc.net/onebook.php?novelid=3200611.

Jung, Sun. (2009). The Shared Imagination of Bishonen, Pan-East Asian Soft Masculinity. Intersections: Gender and Sexuality in Asia and the Pacific 20. http://intersections.anu.edu.au/issue20/jung.htm.

Jung, Sun. (2011). Korean masculinities and transcultural consumption: Yonsama, Rain, Oldboy, K-pop idols. Hong Kong: Hong Kong University Press.

Kamm, Björn-Ole. (2013). Rotten Use Patterns: What Entertainment Theories Can Do for the Study of Boys' Love. In Transnational Boys' Love Fan Studies, eds. Kazumi Nagaike and Katsuhiko Suganuma, special issue, Transformative Works and Cultures 12. https://doi.org/10.3983/twc.2013.0427.

Keengan, Matthew. (2018). Can China's 'Little Fresh Meat' Deliver Big Brand Results? Jing Daily. 31 October 2018. https://jingdaily.com/little-fresh-meat-deliver-results/.

Lang, Miriam. (2003). San Mao and Qiong Yao, a 'Popular' Pair. Modern Chinese Literature and Culture 15.2: 76-120.

Lee, Leo Ou-fan. (1980). 'Modernism' and 'Romanticism' in Taiwan Literature. In Modern Fiction from Taiwan: Critical Perspectives. Indiana, PA: Indiana University of Pennsylvania.

Li, Bin. (2012). The School of Mandarin Duck and Butterfly's Creative Push on Early Chinese Publishing Industry. Asian Social Science 8.12: 164-170.

Li, Shengtao. (2017). Lun wangluo danmei xiaoshuo xushide shengtaixing wenxue tuwei [On the narrative ecological literature breakout of network tanbi novel narrative]. Eastern Forum 02: 83-89.

$\mathrm{Li}$, Xiaomeng. (2020). How powerful is the female gaze? The implication of using male celebrities for promoting female cosmetics in China. Global Media and China 5.1: 5568.

Li, Xiujian. (2017). Lun weijinnanbeichao meixuede sange tezheng [On three aesthetic features of Wei and Jin Dynasties and Southern and Northern Dynasties]. Journal of Zhengzhou University 50.6: 10-13.

Li, Yuzhu. (2007). Web novel, the new trend. Beijing Review. 26 January 2007. http://www.bjreview.com/quotes/txt/2007-01/26/content_53868.htm.

Lilja, Mona and Cathrin Wasshede. (2017). The Performative Force of Cultural Products: Subject Positions and Desires Emerging From Engagement with the Manga Boys' Love and Yaoi. Culture Unbound: Journal of Current Cultural Research 8(3): 284-305. 
Link, E. Perry. (1977). Traditional-Style Popular Urban Fiction in the Teens and Twenties. In Modern Chinese Literature in the May Fourth Era, ed. Merle Goldman, 327-349. Cambridge, MA and London: Harvard University Press.

Liu, James J.Y. (1967). The Chinese Knight Errant. London: Routledge.

Liu, Kang. (2004). Globalization and Cultural Trends in China. Honolulu, HI: University of Hawaii Press.

Liu, Sha. (2017). Cong malisujude liuxing kan dangdai daxuesheng shijieguan [Analysing the world view of current university students from the popularity of Mary Sue TV serials]. Art and Literature for the Masses: 234-235.

Liu, Sha. (2018). Fuhao baoli: malisu dianyingzhong renwu xingxiang shezhide tezheng [Symbolic violence: Features of characters in Mary Sue TV serials]. Journal of Jilin Radio and TV University 203: 147-148.

Liu, Ting. (2009). Conflicting Discourses on Boys' Love and Subcultural Tactics in Mainland China and Hong Kong. Intersections 20. http://intersections.anu.edu.au/issue20/liu.htm.

Liu, Zhan. (2009). Hongloumeng zhong de tongxinglian shuxie yanjiu [On the depictions of homosexuality in Hongloumeng]. Masterpieces Review 11: 50-52.

Louie, Kam. (1991). The macho eunuch: The politics of masculinity in Jia Pingwa's 'Human Extremities'. Modern China 17.2: 163-187.

Louie, Kam. (1999). Sexuality, masculinity and politics in Chinese culture: The case of the 'Sanguo' hero Guan Yu. Modern Asian Studies 33. 4: 835-859.

Louie, Kam. (2000). Constructing Chinese Masculinity for the Modern World: with Particular Reference to Lao She's The Two Mas. China Quarterly 164: 1062-1078.

Louie, Kam. (2002). Theorising Chinese masculinity: Society and gender in China. Cambridge, UK: Cambridge University Press.

Louie, Kam. 2003. Chinese, Japanese and global masculine identities. In Asian Masculinities: The Meaning and Practice of Manhood in China and Japan, eds. Kam Louie and Morris Low, 1-16. London and New York: RoutledgeCurzon.

Louie, Kam. 2012. Popular culture and masculinity ideals in East Asia, with special reference to China. The Journal of Asian Studies 71.4: 929-943.

Louie, Kam. 2013. Globe-trotting Chinese Masculinity: Wealthy, Worldly and Worthy. In Diasporic Chineseness after the rise of China: Community, culture and communication, eds. Julia Kuehn, Kam Louie and David M. Pomfret, 47-66. Vancouver: University of British Columbia Press.

Louie, Kam. 2014. Chinese masculinity studies in the twenty-first century: Westernizing, Easternizing and globalizing wen and wu. NORMA: International Journal for Masculinity Studies 9.1: 18-29.

Louie, Kam and Louise Edwards. (1994). Chinese masculinity: Theorising 'wen' and 'wu'. East Asian History 8: 135-148.

Martin, Wallace. (1986). Recent Theories of Narrative. Ithaca, NY: Cornell University Press.

McLelland, Mark. (1999). Gay Men as Women's Ideal Partners in Japanese Popular Culture: Are Gay Men Really a Girl's Best Friends? U.S.-Japan Women's Journal. English Supplement 17: 77-110.

McLelland, Mark. (2000). The Love Between 'Beautiful Boys' in Japanese Women's Comics. Journal of Gender Studies 9.1: 13-25.

McLelland, Mark. (2005). The World of Yaoi: The internet, censorship and the global 'boys' love' fandom. Australian Feminist Law Journal 23(1): 61-77.

McLelland, Mark. (2015). Regulation of manga content in Japan: What Is the future for BL? In Boys Love Manga and Beyond: History, Culture, and Community in Japan, Eds. Mark McLelland, Kazumi Nagaike, Katsuhiko Suganuma and James Welker, 253-273. Jackson: University Press of Mississippi.

McLelland, Mark. (2016). New Media, Censorship and Gender: Using Obscenity Law to Restrict Online Self-Expression in Japan and China. In Routledge Handbook of New 
Media in Asia, eds. Larissa Hjorth and Olivia Khoo, 118-129. Abingdon: Routledge.

McLelland, Mark. (2017). Introduction. In The End of Cool Japan: Ethical, Legal, and Cultural Challenges to Japanese Popular Culture, ed. Mark McLelland, 1-30. London: Routledge.

McLelland, Mark and James Welker. 2015. An introduction to 'Boys Love' in Japan. In Boys Love Manga and Beyond: History, Culture, and Community in Japan, Eds. Mark McLelland, Kazumi Nagaike, Katsuhiko Suganuma and James Welker, 3-20. Jackson: University Press of Mississippi.

Nagaike, Kazumi. (2003). Perverse Sexualities, Perverse Desires: Representations of Female Fantasies and 'Yaoi Manga' as Pornography Directed at Women. U.S.-Japan Women's Journal 25: 76-103.

Nagaike, Kazumi. (2015). Do heterosexual men dream of homosexual Men?: BL fudanshi and discourse on male feminization. In Boys Love Manga and Beyond: History, Culture, and Community in Japan, Eds. Mark McLelland, Kazumi Nagaike, Katsuhiko Suganuma and James Welker, 199-209. Jackson: University Press of Mississippi.

Nagaike, Kazumi and Tomoko Aoyama. (2015). What is Japanese 'BL Studies?' A Historical and Analytical Overview. In Boys Love Manga and Beyond: History, Culture, and Community in Japan, Eds. Mark McLelland, Kazumi Nagaike, Katsuhiko Suganuma and James Welker, 119-140. Jackson: University Press of Mississippi.

Nielsen, Inge. (2000). Caught in the Web of Love: Intercepting the Young Adult Reception of Qiongyao's Romances On-Line. Acta Orientalia Academiae Scientiarum Hungaricae 53.3/4: 235-253.

$\mathrm{Ng}$, Lynda. (2015). China's elusive truths: Censorship, value and literature in the Internet age. In Censorship and the Limits of the Literary: A Global View, ed. Nichole Moore, 233246. New York, London: Bloomsbury.

Ouyang, Youquan. (2011). Chinese literature's transformation and digital existence in the new century. Social Sciences in China 32(1): 146-165.

Pagliassotti, Dru. (2010). Better than romance? Japanese BL manga and the subgenre of male/male romantic fiction. In Boys' love manga: Essays on the sexual ambiguity and cross-cultural fandom of the genre, eds. Antonia Levi, Mark McHarry and Dru Pagliassotti, 59-83. Jefferson, NY: McFarland.

Pflieger, Pat. (1999). Too Good To Be True: 150 Years Of Mary Sue. Paper presented at the American Culture Association Conference.

Ren, Xiang and Lucy Montgomery. (2012). Chinese online literature: creative consumers and evolving business models. Arts Marketing: An International Journal 2.2: 118-130.

Rifkin, Jeremy. (1998). The Biotech Century: Harnessing the Gene and Remaking the World. New York, NY: Tarcher/Putnam.

Smith, Paula. (1973). A Trekkie's Tale. Menagerie 2.

Song, Geng. (2004). The Fragile Scholar: Power and Masculinity in Chinese Culture. Hong Kong: Hong Kong University Press.

Sun, Yingrui and Meng Shi. (2016). Dangdai zhongguo shaonv wenben malisu xianxiangde yishixingtai poxi [Revealing the ideologies of the Mary Sue phenomenon in femaleoriented writing in contemporary China]. Culture Journal 01: 70-73.

Suzuki, Kazuko. (1998). Pornography or Therapy? Japanese Girls Creating the Yaoi Phenomenon. In Millennium Girls: Today's Girls around the World, Ed. Sherrie Inness, 243-267. Lanham: Rowman and Littlefield.

Tan, See Kam. 2016. Three-Women Fiction, Mandarin Ducks and Butterflies. In Tsui Hark's Peking Opera Blues, 148-189. Hong Kong: Hong Kong University Press.

Teo, Stephen. (2009). Chinese Martial Arts Cinema: The Wuxia Tradition. Edinburgh: Edinburgh University Press. 
Tian, Xiaofei. (2015). Slashing Three Kingdoms: A Case Study in Fan Production on the Chinese Web. Modern Chinese Literature and Culture 27.1: 224-277.

Tian, Xiaoli and Michael Adorjan. 2016. Fandom and coercive empowerment: the commissioned production of Chinese online literature. Media, Culture and Society 38.6: $881-900$.

To, Nathan. (2019). Disrupting the sword: The Wuxia legacy of Adam Cheng and the embodiment of Hong Kong cultural memory. Celebrity Studies 10.2: 268-275.

Toku, Masami. (2007). Shojo Manga! Girls' Comics! A Mirror of Girls' Dreams. Mechademia 2: 19-32.

Tse, Michael S. C. and Maleen Z. Gong. (2012). Online Communities and Commercialization of Chinese Internet Literature. Journal of Internet Commerce 11.2: 100-116.

Volpp, Sophie. (2001). Classifying Lust: The Seventeenth-Century Vogue for Male Love. Harvard Journal of Asiatic Studies 61.1: 77-117.

Wang, Buyi. (2020). Nanse jingji bianxian zhilu [The way to monetise males as products]. Biz Leaders. 14 December 2020. https://www.biz-leader.com/newsinfo/983348.html.

Wang, Cathy Yue. (2019). Officially Sanctioned Adaptation and Affective Fan Resistance: The Transmedia Convergence of the Online Drama Guardian in China. International Journal of TV Serial Narratives: 45-58.

Wang, Meng. (2017). Lun fangxia wangwen gaibianju zhongde malisu shi IP shengxing xianxiang [Discussion on the widespread phenomenon of Mary Sue style TV serials adapted from online literature]. Radio and TV Journal 01: 52-53.

Wang, Shaoying. (2018). Fuwenhua shequnzhongde nvxing shenfen rentong yu kongjian jiangou [Identity recognition and space construction of women in rotten culture communities]. Journal of News Research 11: 57-58.

Wei, John. (2014). Queer Encounters between Iron Man and Chinese Boys' Love Fandom. Transformative Works and Cultures 17. https://doi.org/10.3983/twc.2014.0561.

Wei, Wei. (2008). Resistance in Dreaming: A Study of Chinese Online Boy's Love Fandom. Paper presented at the Annual Meeting of the International Communication Association. Montreal, Quebec, Canada.

Wong, Alvin K. (2020). Towards a queer affective economy of boys' love in contemporary Chinese media. Continuum 34.4: 500-513.

Wood, Andrea. 2006. Straight Women, Queer Texts: BoyLove Manga and the Rise of a Global Counterpublic. Women's Studies Quarterly 34.1/2: 394-414.

Wu, Cuncun. 2003. 'Beautiful boys made up as beautiful girls': anti-masculine taste in Qing China. In Asian Masculinities: The Meaning and Practice of Manhood in China and Japan, eds. Kam Louie and Morris Low, 19-40. London: RoutledgeCurzon.

$\mathrm{Wu}$, Xiaoling and Xiao Zhang. 2018. Wangluo yanqing xiaoshuode yanwenhua yinzi yu zhuliuwenhuade shoubian [Subcultural factors of online romance novels and the incorporation into the mainstream culture]. Journal of Southwest Jiaotong University 19.1: 35-41.

Xiao, Yingrong. 2018. Lishi yanyi yu dongfang qihuan de nvpin yindu-Ping Feitianyexiang Tianbaofuyaolu [Historical romance and Eastern fantasy on the female-oriented platform-Analysing Feitianyexiang's Tianbaofuyaolu]. Chinese Journal of Literary Criticism 01: 126-127.

Xiao, Yingrong. 2019. Dianfu qingchengzhilian, chongxie moshiwenming-Ping Feitianyexiang Erlingyisan [Deviating the earthshaking love and rewriting the apocalyptic civilisation-Analysing Feitianyexiang's 2013]. Contemporary Chinese Literature Studies 02: 133-134.

Xiao, Yingxuan. 2018. Zhaifu shuangxiu-Nvxingxiang danmei danyuan daodu [Combination 
of Otaku and rotten-Introduction of female-oriented danmei]. Theory and Criticism of Literature and Art 05.

Xie, Tingyu and Hanwen Zhang. 2020. Fanquan wenhua de zhexue xingsi [Philosophical reflection on fandom culture]. Guangming Daily. 27 April 2020.

https://wap.gmdaily.cn/article/9ca6637b83f94f23a3e91d686869e113.

Xie, Ying and Minggang Peng. 2018. Attitudes Toward Homosexuality in China: Exploring the Effects of Religion, Modernizing Factors, and Traditional Culture. Journal of Homosexuality 65.13: 1758-1787.

$\mathrm{Xu}$, Yanrui and Ling Yang. 2013. Forbidden love: incest, generational conflict, and the erotics of power in Chinese BL fiction. Journal of Graphic Novels and Comics 4:1: 30-43.

$\mathrm{Xu}$, Yanrui and Ling Yang. 2014. Funv Funan: Kuaguo wenhua liudongzhongde danmei, fuwenhua yu nanxingqizhide zaizao [Rotten girls and rotten boy: Danmei, rotten culture and representation of masculinity in transcultural communication]. Cultural Studies 03: 3-25.

Yang, Ling and Hongwei Bao. 2012. Queerly intimate: Friends, fans and affective communication in a Super Girl fan fiction community. Cultural Studies 26.6: 842-871.

Yang, Ling and Yanrui Xu. 2016. Danmei, Xianqing, and the making of a queer online public sphere in China. Communication and the Public 1.2: 251-256.

Yang, Ling and Yanrui Xu. 2017a. 'The love that dare not speak its name': The fate of Chinese danmei communities in the 2014 anti-porn campaign. In The End of Cool Japan: Ethical, Legal, and Cultural Challenges to Japanese Popular Culture, ed. Mark McLelland, 163183. London: Routledge.

Yang, Ling and Yanrui Xu. 2017b. Chinese Danmei Fandom and Cultural Globalization from Below. In Boys' Love, Cosplay, and Androgynous Idols: Queer Fan Cultures in Mainland China, Hong Kong, and Taiwan, eds. Lavin Maud, Ling Yang and Jamie Jing Zhao, 319. Hong Kong: Hong Kong University Press.

Yi, Erika Junhui. 2013. Reflection on Chinese boys' love fans: An insider's view. Transformative Works and Culture 12. DOI: https://doi.org/10.3983/twc.2013.0424.

Yin, Pumin. 2005. Web writing. Beijing Review. 25 August 2005. http://beijingreview.sinoperi.com/en200534/694468.jhtml.

Zeng, Wenting. 2017. Qianxi danmei wenhua chuanbo guocheng-Yi wangluo chuanbo he funv jiaodu fenxi [Analysis of the spread process of danmei culture-From the aspects of Internet communication and rotten girls]. Chuanbo yu Banquan 44.1: 136-137.

Zhang, Chunyu. 2016. Loving Boys Twice as Much: Chinese Women's Paradoxical Fandom of 'Boys' Love' Fiction. Women's Studies in Communication 39(3): 249-267.

Zhang, Qian and Keith Negus. 2020. East Asian pop music idol production and the emergence of data fandom in China. International Journal of Cultural Studies 23.4: 493-511.

Zhang, Suli. 2012. Hongloumeng zhong jiamu xingxiang fenxi [Analysing the image of Grandmother Jia in Dream of the Red Mansion]. Journal of Jilin Radio and TV University 04: 86-87.

Zhang, Xinruo. 2015. Tan malisuju fuyu xinshengdai daxuesheng de nvixingguan [The feminist view of Mary Sue TV serials and its influence on current university students]. Business 51: 233-234.

Zhang, Yongqing. 2003. Ed. Xinshiqi Wenxue Sichao [Literary Trends in the New Age]. Beijing: China Renmin University Press.

Zhang, Yongqing. 2011. Reflecting on online literature. Social Sciences in China 32(1): 182190.

Zhao, Lihua. 2015. Cong Beicheng tianjie kan zhongguo nantongxinglianzhe de shengcunzhuangkuang [On the status quo of male homosexuals in China from Beicheng 
tianjie]. Journal of Mudanjiang University 10: 61-63.

Zheng, Li. 2017. Danmei wenhua zai qingshaonian nvxing qunti zhongde chuanbo yu yingxiang yanjiu [The spreading and influence of tanbi culture in adolescent females]. Journal of Shandong Youth University of Political Science 02 : 29-33.

Zheng, Muwen. 2017. Qianxi guochan dianshiju zhongde malisushi shenhua [Analysing the Mary Sue plots in Chinese TV serials]. Home Drama 09: 124-125.

Zhao, Yao and Anna Madill. 2018. The heteronormative frame in Chinese Yaoi: integrating female Chinese fan interviews with Sinophone and Anglophone survey data. Journal of Graphic Novels and Comics 9.5: 435-457.

Zheng, Li. 2017. Danmei wenhua zai qingshaonian nvxing qunti zhongde chuanbo yu yingxiang yanjiu [The spreading and influence of tanbi culture in adolescent females]. Journal of Shandong Youth University of Political Science 02: 29-33.

Zheng, Lin. 2014. Danmei cheng wangluo xiaoshuo zuiremen ticai, yongyou dapi funv duzhe [Danmei becomes the most popular genre of online fiction, with legions of rotten fangirl readers]. Morning Express. 21 March 2014. http://www.chinanews.com/cul/2014/0321/5980042.shtml.

Zheng, Xiqing. (2019). Survival and Migration Patterns of Chinese Online Media Fandoms. Transformative Works and Cultures 30. DOI: https://doi.org/10.3983/twc.2019.1805.

Zhou, Chunfa. (2017). 'Nan Se consumption': Cultural analysis of advertisements featuring male celebrities for female cosmetics. Culture \& Communication 6.1: 1-5.

Zhou, Ruchang. (1993). Hongloumeng yu 'qingwenhua' [Dream of the Red Chamber and the 'culture of sentiment']. Hongloumeng xuekan 1: 67-78.

Zhou, Yiqi and Qi Li. (2016). Funv qunti yu danmei yanwenhua de xinmeiti chuanbo [New media communication of rotten girl groups and danmei subculture]. Media Observation 06: 31-33.

Zhu, Ying and Meng Zhang. (2015). Shenfen rentong shiyexia danmei miqunde wangmei shiyong [The use of Internet media of danmei fandom under the view of identity recognition]. News World 11: 133-134.

Zsila, Ágnes, Dru Pagliassotti, Róbert Urbán, Gábor Orosz, Orsolya Király and Zsolt Demetrovics. (2018). Loving the love of boys: Motives for consuming yaoi media. PLoS One 13(6): e0198895. doi: 10.1371/journal.pone.0198895.

Zsila, Ágnes and Zsolt Demetrovics. (2017). Redrawing the Boundaries of Gender and Sexuality: A Psychological Reconceptualisation of the Boys' Love Phenomenon. Intensities: The Journal of Cult Media 9: 34-49. 